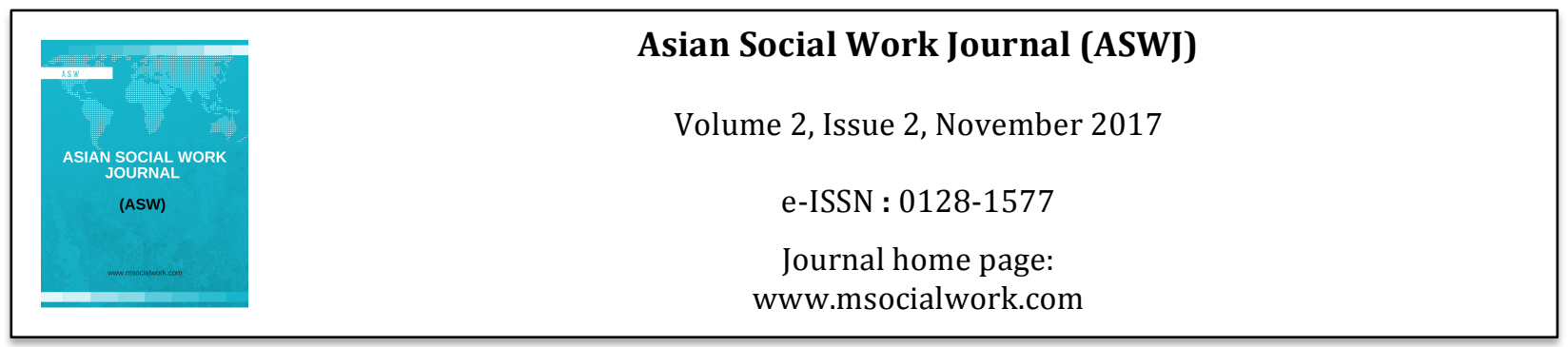

\title{
Vulnerability Life of LGBT Community in Curup Rejang Lebong Regency of Bengkulu Province
}

\author{
Yessilia Osira $^{1}$, Bayu Risdiyanto ${ }^{2}$, Nugroho Iskandar ${ }^{1}$ \\ 1Bengkulu University \\ 2Bengkulu Dehasen University \\ Corrrespondence: Yessilia Osira (yosira@unib.ac.id)
}

\begin{abstract}
Lesbian, Gay, Bisexual, and Transgender, or we known as LGBT is one of community that has vulnerability life. This research indicates that besides interacting and experiencing various disorders in social intersection aspects with family and society, healthy, education and work aspects, actually the LGBT's community also has adaptation ability even utilizing to increase their well-being. Base on that, should be made social protection efforts through various activities of capacity building and social advocacy for LGBT's community in facing their vulnerability.
\end{abstract}

Key words: vulnerability life, LGBT community, well-being, social advocacy

\section{Introduction}

Lesbian, Gay, Bisexual and Transgender or as we known with the acronym LGBT is not new in the history of human development. This term is used since the 1990s replaced the phrase "gay community" since it is more representative for groups of diverse sexual orientation. Lesbian is a sexual orientation towards same-sex (women), gay or homosexual is a sexual orientation to love same-sex (male). Bisexual, sexual orientation could be both to women, and men, as well as transgender, someone who wants to change its physical form, at birth, such as men want to be a woman or vice versa.

Debate or pros and cons about the existence of LGBT also have been recorded in various religious scriptures (Noviandy:2012). In Indonesian context, besides majority of public view against the existence of LGBT, whether by reason of "sin", "deviant behavior", "disease" and other opposition terms, there is also a group that accepts and even supporting the existence of the LGBT community. Some cultures in Indonesia even give room for acceptance of the LGBT community, such as five genders in Bugis culture (South Sulawesi) include men, women, calalai or women who are effeminate manner, calabai or female tomboy like men and bissu, which is not a man nor a woman. Even in the present context, we also recognize some non-governmental organizations as a forum for the LGBT community as Swara Srikandi in Jakarta, Gaya Nusantara LGBT, Arus Pelangi LGBT, Lentera Sahaja, Indonesian Gay Society in Yogyakarta, including the Association of Rainbow Bengkulu (IPB) and the Association of Shemale Rejang Lebong (IKWRL), Rejang Lebong regency of Bengkulu province. Besides, based on information from Lulu, a caretaker IKWRL, it is known that until the beginning of 2017, there are five transgender communities in five regencies in Bengkulu, include: Association of Transgender North Bengkulu (IWABU), Association of Transgender Lebong, Association of Transgender Kepahyang, Association of Transgender Bengkulu City and IKWRL. 
The Ministry of Health report cited from the National AIDS Mitigation Commission reveals the number of Man having Sex with Men (MSM) aka gay has been reached millions. Based on Ministry of Health estimated in 2012, there were 1,095,970 MSM either visible or not. More than five percent (66 180) contracted HIV. Meanwhile, the UN agency predicts the number of LGBT much more, three million people in 2011 (Republika.co.id Saturday, 23 January 2016). IKWRL have its own estimate of the number of LGBT in Bengkulu province, ranges above 400 people. Of course, this amount only that were previously affordable by some communities, but the actual number is far above the estimate.

Several cases involving the LGBT community and take a lot of public attention in Indonesia at 2016 has not only increased the pros and cons debate about the existence of LGBT in Indonesia, but the least impact on the existence of discrimination and the negative stigma attached to the LGBT community. The research results were released by Arus Pelangi in 2013 mentions 89.3\% LGBT in Indonesia have experienced violence, with $79.1 \%$ in the form of psychological violence, $46.3 \%$ in the form of physical violence, $26.3 \%$ in the form of economic violence, $45.1 \%$ in the form of sexual violence, and $63.3 \%$ in the form of culture. From many violence cases, $65.2 \%$ were looking for friends help, and even $17.3 \%$ victims of violence was ever attempted suicide.

Based on this background, we conducted research with title "Vulnerability Life Of LGBT Community in Curup Rejang Lebong Regency Of Bengkulu Province. Some reasons underlying for site selection include: 1) Rejang Lebong Regency is known in Bengkulu community as one of the locations with the largest LGBT community population with various activities. 2) In Curup discovered a LGBT community which already starting to organize the Association of Shemale Rejang Lebong (IKWRL) making it easier for researchers to reach out to the LGBT community through the agency.

Based on this background, the formulation of the problem in this study is: How does the vulnerability of LGBT community living in Rejang Lebong Curup Bengkulu Province? The formulation of the problem consists of sub problems as follows: 1) how do the characteristics of the LGBT community? 2) What level of exposure to the problems experienced by the LGBT community? 3) What level of sensitivity to the problems experienced by the LGBT community? 4) How is the adaptability of the LGBT community in dealing with problems?

This study aims to assess the profile of LGBT community in Curup, as well as examine how their lives intersect with problems and disorders, assessing the effects of problems and disorders and also assess their adaptability to face the problems and disorders.

\section{Literature}

Vulnerability is a concept in the context of climate change which is usually accompanied by the concept of adaptation and resilience. The vulnerability in this case is defined as a condition when a system was rocked by disturbances from outside the system up beyond the critical (critical threshold), causing the system has the ability to survive and make a change (transformation). There are three components of vulnerability affecting adaptation strategies a social system to cope with change: 1 ) the level of exposure, i.e. the extent to which the system (pattern of community life) intersects with the disorder. In this study of course related to the extent to which the LGBT community intersects with various problems and disorders. 2) The level of sensitivity, defined as the effect or impact of the problem or disorder received either directly or indirectly by the LGBT community. 3) Adaptability (capacity of response), is the system's ability to respond disturbances, balance the potential impacts that will occur, take advantage of opportunities, and fused with the consequences that may arise from a change (Gallopin 2006).

\section{Methodology}

This study uses quantitative and qualitative approaches. Informant determination conducted through sampling purposive technique. Collecting data conducted through observation and questionnaires deployment to 30 people LGBT community in the region Curup as well as interviews and focus group discussions with the LGBT community and the parties concerned with the existence of the LGBT community. Data collection is also conducted through documentation study technique. 
The collected data of this study include characteristics of the LGBT community, the vulnerability live of the LGBT community in the aspect of social interaction, health, education and vulnerability at work. The collected data is then processed and analyzed quantitatively and qualitatively so as to produce a full description of the vulnerability of the LGBT community living in Rejang Lebong Curup Bengkulu Province.

\section{Results}

\section{Characteristics of LGBT Community}

Based on information from the board IKWRL, there were about 102 people joint in the institution. According to them, the number is still small compared with the LGBT population in the middle of society. Negative stigma that embedded by public to LGBT community makes them do not want to put forward its existence directly. From LGBT community, the transgender is a community which easily to recognized in the midst of community association, while the lesbian, gay, and bisexual relatively not easy to recognized except we have known them for a long time.

The results showed that from 30 informants, known $6.6 \%$ aged eighteen years and under, $10 \%$ aged 26 years, and $83.4 \%$ majority of the LGBT community aged between $19-25$ years. Gender of the community, consist of $86.6 \%$ men and the rest $13.4 \%$ were female. The results also mention that the whole the informant who completed questionnaires, $43.3 \%$ sexual oriented as gay, $43.3 \%$ claimed to be a transvestite, and $13.3 \%$ claimed to be a lesbian. The data indicates that men ages 19-25 years are more extroverted to express themselves part of the LGBT community compare with the women. This is understandable, considering LGBT is a sensitive issue which if avowed inappropriately could cause negative stigma, and men are known to be more open about his condition than women. This Negative Stigma is one of the factors that inhibit us to know certainly the populations of LGBT community and their vulnerability life.

The results of this study stated that the age of the LGBT community when it began to realize there are different sexual orientation than most people starting at age $12-15$ years (junior high school) as much as $83.3 \%$, age $16-18$ years (high school) of about 13,3\% and the remainders are less than 12 years old (elementary school age).This indicates that the awareness of sexual orientation grows in the age of junior secondary education and postsecondary education (junior and senior). They also stated that they were initially feel strange, silent, wondering, shy and insecure of knowing differences in sexual orientation. The feelings were an indication of indecision when their sexual orientation is different from the others. In the context of therapy, this should be an important moment in the effort to changing attitudes and behavior. If not, the decision that can make comfort will be taken by them, and this is not necessarily appropriate with the values or norms of people majority. This condition also needs to be concern together how importance of sexual education or reproductive health education early or since primary school and even from educational kindergarten, so that we can detect any abnormalities of sexual orientation and can be anticipated through a variety of psychosocial therapy efforts and if needed also medical therapy.

\section{Problems Exposure Level of LGBT Community}

The results of this study indicate that the LGBT community intersects with various problems and disorders, including:

\section{Vulnerability LGBT community in a family environment}

This study shows that of the 30 informant questionnaire, only $6.6 \%$ who claim that there are family members who have a sexual orientation as well as himself. This shows that their sexual orientation is not caused by, or directly related to the sexual orientation of his family. Nevertheless it needed to be concern that $83.3 \%$ of the informants claimed there are unpleasant experience in a family environment which is traumatic (always remember), including: sexual abuse, bullied (derided, scolded) by other family members, and humiliated as a result of the attitude and behavior is incompatible with the concept of the role of men and women that adopted and served by the family. It also shows that the position of the family is very important to be actively involved in helping family members 
determine the sexual orientation. Reproductive health education is not only aimed at high-risk communities but also to the entire family, so if detected sexual orientation neglect at an early age can be handled.

The result of this study also indicates that only $26.7 \%$ of informants stated that now their families know their sexual orientation. It is because the family felt they were adults and have the right to determine their own life. It can be seen from the research data; generally they have been 23 to 26 years. Nevertheless, the majority of informants or $73.3 \%$ stated that their families do not know their sexual orientation choice. This condition actually can be a potential conflict between the informants with the family which if not treated immediately will makes conflict that can cause disharmonious family. However, the efforts to be frank for the LGBT community to his family is also not an easy task considering the values / norms of the majority of people do not want their family members to be the LGBT community. Therefore we need a good facilitator such as social workers who are able to mediate and help to anticipating the potential conflicts in the family.

\section{Vulnerability of the LGBT community in the Society Environment}

In interacting with the wider community, we often assume that the majority of people will oppose and "judge" the existence of the LGBT community, but this study shows that the LGBT community in Curup feel that people accept and understand the choices of their sexual orientation reached $43.3 \%$, while stating that people deny the existence of the LGBT community is only about $16.7 \%$, and stating do not care or be abstain (not accept but also not deny) ranging up to $40 \%$. Nonetheless, public acceptance is generally directed to transgender community (shemale), while rejection is more aimed at the gay and lesbian community. In the context of social interaction, we need to examine further how the people in Curup can accept the existence of the LGBT community in social life. This is different from what happened with the LGBT community in the city of Bengkulu. Lulu, a caretaker IKWRL states:

.......In Rejang Lebong, especially Curup we could mingle comfortably with the people
....They did not nosy ... .we can work smoothly without fear of insulting people or expel
our existence ... even for years in Curup government also facilitates organization of
prettiest transvestite contest ... until yesterday, because of Saiful Jamil case and cases in
Depok, the government eventually prohibit us ... but our brothers in the Bengkulu city,
their fate just not as good as in Curup..In Bengkulu, they often sould romp with the
municipal police ... besides in addition to have activities they are also have difficulty
because often dispersed by community...

Although today people relatively accept their existence, but in this research are also states that about $73.3 \%$ of the informants had experienced of uncomfortable treatment from society, such as be told sissy, tomboy, no girl/boyfriend and be ridiculed by other taunts. They stated those people attitudes who do not accept their existence from the beginning actually not accompanied by community action to direct or show the way how to deal with the differences in sexual orientation. It can be said that people just "railed: without any" solution ". This study showed that only about $26.7 \%$ states that the public accept the existence of the LGBT community.

\section{Vulnerability of the LGBT Community in Economic aspects}

In connection with economic / employment aspect, when asked about the difficulties or obstacles in fulfill the economy needs, $40 \%$ of the informants said they encountered obstacles, which is caused by their lack of knowledge and business skills. It is because of their low education levels. However, $60 \%$ of the informants claimed not encounter obstacles or difficulties in fulfill the economic requirement. This happens because they generally already have jobs such as opening a salon, bridal makeup, and helping their family businesses. This shows that economically, the LGBT community is not a community that becomes a burden both for family/community and also for the government. Nonetheless, the LGBT community is still needs guidance and coaching of increasing capacity in conducting productive economic activities.

\section{Vulnerability of the LGBT Community in Health aspects}

The results showed that related to the question of the difficulties in health care, $63.3 \%$ of the informants claimed had no health problems, and $36.7 \%$ of the informants claimed had health problems because of unhealthy lifestyles 
such as drinking liquor (alcohol), smoking, sleep late till morning. Although only a minority who experience health problems, basically the LGBT community is susceptible to have health problems due to the behavior of high-risk sex, but also susceptible to have mental health disorders as a result of stigma negative along the abuse and violence experienced in interacting with the family and community environment.

\section{Vulnerability of the LGBT community in aspects of education}

In connection with education aspect, the study showed that $63.3 \%$ of the informants claimed have no problems in the field of education. They state that they able to complete junior and senior high school. Nevertheless $36.7 \%$ stated that they had problems in the aspect of education. The problems which often experienced include: frequent harassment and violence (bullied). In addition, the educational issue also due to the LGBT community is in part have limitations or difficulties in the economic field.

\section{The Sensitivity Level of the LGBT Community Issues}

This level of sensitivity is related to the effects or consequences experienced or felt by the LGBT communityrelated to issues or disorders that suffered. The results indicated that there are interplay correlation between problems one with another. In the context of the development of a person that indicates himself as part of the LGBT community, starting from indecision on sexual orientation which is different from the majority of society, causing he/she ridiculed, sexually abused or bullied both verbal and physical abuse by family, community, school and work environments. As a result, he faces obstacles in social interaction even with the family, society and the school and work environments. This causes he/she could not able to complete education well, which is causing he/she difficult to access jobs that are economically affected. Disruption in this economic aspect also caused $\mathrm{him} /$ her difficult to complete the education. The lake of economic and education resources, coupled with the pressure in social interaction led him/her to faces health problems. The whole problems or disruption of the LGBT community makes them faces social dysfunction, which in the context of the social work profession marked by the inability to fulfill the demands of society.

\section{Adaptability to the LGBT Community Issues}

The results of this study indicates the ability of the LGBT community in responding the experienced problems or interference, responding the disturbances, balancing the potential impacts that will occur, take advantage of opportunities, and fused with the consequences that may come from the existence of changing, it can be seen from the ability of some communities which able to capture employment opportunities such as opening a beauty salon and bridal makeup, entrepreneurship so economically they are less burden to others. Efendi (IKWRL community member) states:

\footnotetext{
.....Basically we do not beg for productive economic assistance, the majority of us generally already have jobs that can support families, such as opening a beauty salon and bridal make up ... even we are also have activity of routine religious studies and other activities ...
}

The adaptability is also seen from the motivation to increase their capacity both in social interaction, health care, education through association which initiated together by the LGBT community. IKWRL is one community that embodies their activities.

\section{Conclusion}

Results of research on the vulnerability of the LGBT community living in Rejang Lebong Curup Bengkulu Province can be concluded: 1) The LGBT community in Curup dominated by the presence of gays and transsexuals (transgender), and lesbian. Awareness of their sexual orientation generally occurs at age 12 to 18 years, marked by their indecision. At times, in real that the environment, community, schools and even families not be a comfortable place for them to discuss sexual orientation, but instead of sexual and verbal violence that 
actually embarrass them. This condition is becoming blurred when most families until now did not know the sexual orientation of their members, and this becomes a potential conflict which is not only detrimental to the child but also the family and society around. 2) LGBT Community in Curup mostly experienced various problems or disorders both in the social interaction aspect with family and community, problems in educational, health and economic aspects as well as jobs. As the result of these problems, the LGBT community experiencing stress or disorders such as pain, mild psychiatric disorder, even drugs dependency. Besides, they are also having disharmony in the family and society. Nevertheless, some members of the LGBT community are able to adapt with various kinds of problems and disorder. One form of such adaptation is the ability to entrepreneur such as opening a salon and bridal makeup, develop their potential through social institutions such as IKWRL activities in which there have meetings, discussions, lectures, doing sports and various beauty contests.

\section{References}

Gallopin GC. (2006). Linkages Between Vulnerability, Resilience, and Adaptive Capacity. Global Environmental Change (vol.16). retrieved November 22, 2015 .available at: doi: 10.1016 / j.gloenvcha.2006.02.004 Global Environmental Change,16, 293-303.

Millen, Anelli. (2006). Capacity Building (free trans). Yogyakarta: Updates.

Noviandy, (2012). LGBT dalam Kontroversi Sejarah Seksualitas dan Relasi Kuasa (Sebuah Pengantar), Jurnal Momentum, 2, 2.

Sugiyono. (2007). Quantitative Research Methods, Qualitative and R \& D. Bandung: Alfabeta.

Suharto, Edi, Ph.D. (2009). Poverty \& Social Protection in Indonesia. Bandung: Alfabeta

Wahyu Rahardjo, (2007). Homophobia dan Penolakan Masyarakat, serta Hubungannya dengan Bicultual Identity Pada Covert Homoseksual, Jurnal Penelitian Psikologi No. 2 Volume 12 Desemer 2007.

Yudiyanto, Fenomena Lesbian, Gay, Biseksual Dan Transgender (LGBT) Di Indonesia Serta Upaya Pencegahannya, Jurnal NIZHAM, 5, 1.

USAID, UNDP, Mei (2014). Hidup Sebagai LGBT di Asia - Laporan Nasional Indonesia, Tinjauan dan Analisa Partisipatif Tentang Lingkungan Hukum dan Sosial bagi Orang dan Masyarakat Madani Lesbian, Gay, Biseksual dan Transgender (LGBT).

Fauziah, Nanda, Al-Farabi \& Makhrian, Andi (2014). Space Gay Identity in Social Interaction (Study dramaturgical At Gay Community In Bengkulu City). Undergraduated thesis, University of Bengkulu. Republika.co.id. Saturday, 23 January 2016. 